\title{
Application of risk management principles in macroeconomic regulation
}

\author{
Uliana Aftakhova $^{1 *}$, Eugeny Zhulanov ${ }^{2}$ and Aleksandr Aftakhov ${ }^{1}$ \\ ${ }^{1}$ Perm National Research Polytechnic University, 614990 Komsomolsky Ave. 29, Perm, Russia \\ ${ }^{2}$ Perm National Research Polytechnic University, 614990 Komsomolsky Ave. 29, Perm, Russia
}

\begin{abstract}
The article confirms the urgency of coordination strategic and tactical management of the country social-economic system on the basis of the principles and methods of risk management. It proposes an economic-mathematical dynamic model, describes an advanced complex of forward and backward linkages between national economy and its managerial system. This approach allows predicting and implementing development vector of a system more accuracy on the way to achieving its strategic goals. The authors' approach was tested on the base of the social and economic system of the Perm Region.
\end{abstract}

\section{Introduction}

The analysis of today's social and economic development programmes of the Russian Federation and its subjects revealed that only a list of social and economic indicators to be reached by the end of their implementation is accounted for. However, clearly defined tools for reaching specified strategic, let alone tactical, objectives are described rather sparsely, if at all. As a rule, only a list of budget allocation options is given, with performance evaluation mechanisms totally ignored [1, 2]. This stimulates the need for drafting a national policy that would facilitate making managerial decisions based on these mechanisms, as well as realistic planning and reaching tactical and strategic objectives in the social and economic system of the country [3].

The approach proposed by the authors implies a dramatic change in national policy in favour of principles and methods of up-to-date management. In particular, strategic and tactical planning and risk management. Thus, national policy assumes the aspect of preventive risk management, that is, a set of rules on making national policy decisions in risk management in the society by using specialized economic tools.

\section{Literature review}

The phenomenon of risks and instruments of their minimization does not lose its historical relevance. There are known attempts of prophets and fortune tellers of Ancient Rome and Ancient China to develop risk management techniques on the basis of ritual procedures. In particular, on the basis of the ancient Chinese "Book of changes" strategic state decisions were made for many centuries. It is this work today to be considered the first comprehensive risk management system. It is well known that behind the scenes of the Delphic Oracle there was a large group of priests working, collecting and analyzing various world information [2].

Despite such a long history of study, so far modern science has not developed an unambiguous theory of risk management. Since there is no common understanding of the "risk" category, the article authors define it as an activity related to the decision-making process to overcome uncertainty in the country's social-economic system.

Risk management is a procedure that is methodologically close to exact sciences [3]. Any socialeconomic system is described by its objective characteristics (parameters), which are inherent to it at any given moment of time. Therefore, the level of uncertainty characteristic of each parameter of this system will differ depending on the change in the external and internal environment. Thus, the strategic objective of risk management involves the fulfillment of a designated mission of the system, the achievement of its goals and objectives, the implementation of its strategic plan, and actions that assess the change in the state of the system in relation to the fulfillment of its mission. Ongoing risk management involves actions that actually ensure the implementation of mechanisms for day-to-day advancement of the system towards its goal. Thus, risk management system unites all actions that contribute to reducing the probability and magnitude of the system deviation from achieving its own strategic goal [3].

The paradigm of preventive risk management is based on the theory of integrative management, according to which the subject of management carries out navigation through risky landscapes. The movement trajectory of the object under control is a navigation strategy (ensuring stable development of the subjects of the Russian Federation and stable common economic growth, as a consequence) and navigation tactics (tasks

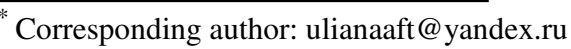


solved to achieve a strategic goal, based on the methodical forecasting tools, allowing to preventively minimize risks). The results of the study made it possible to identify the functional features of the preventive risk management system, which are presented in the table (see Table 1).

Table 1. Contents of functions of the preventive risk management system in the social-economic system

\begin{tabular}{|c|c|}
\hline Function & Contents \\
\hline Axiological & $\begin{array}{l}\text { definition of the working population } \\
\text { value and their subsequent } \\
\text { generations on the basis of economic } \\
\text { development potential of industrial } \\
\text { production }\end{array}$ \\
\hline Limiting & $\begin{array}{l}\text { restriction of industry negative } \\
\text { impact on the life quality of the } \\
\text { population by improving working } \\
\text { conditions and environmental } \\
\text { activities of industrial enterprises }\end{array}$ \\
\hline Stimulating & $\begin{array}{l}\text { arrangement } \text { of favourable } \\
\text { conditions for self-realization and } \\
\text { maximizing the well-being of the } \\
\text { entire population }\end{array}$ \\
\hline Stabilizing & $\begin{array}{l}\text { ensuring sustainable progressive } \\
\text { industrial development by } \\
\text { minimizing negative socio-economic } \\
\text { and environmental impacts and } \\
\text { intensifying innovation and } \\
\text { technological modernization as a } \\
\text { result of human potential }\end{array}$ \\
\hline Compensating & $\begin{array}{l}\text { compensation for the negative } \\
\text { impact of industrial development on } \\
\text { the life quality of the population }\end{array}$ \\
\hline Evolutional & $\begin{array}{l}\text { ensuring coevolutionary } \\
\text { development of industry and civil } \\
\text { society or mutual development of } \\
\text { industrialization and civilization }\end{array}$ \\
\hline Harmonizing & $\begin{array}{l}\text { harmonization of systemically } \\
\text { interconnected solutions of social, } \\
\text { ecological, innovative, technological } \\
\text { and branch tasks of regional and } \\
\text { national economy development, } \\
\text { minimizing damage to each of these } \\
\text { spheres }\end{array}$ \\
\hline
\end{tabular}

These functional features defined the content of the management fad of risk management "Social-SOS". The proposed concept is to implement simultaneously three main approaches to the management of the socialeconomic system [4]:

- social-strategic approach, consisting of priority social and environmental goals identification while designing, creating and developing the production;

- social-responsible approach, assuming the determination of a mechanism to redistribute powers and responsibilities of social-economic system management subjects according to the criterion of the significance of change dynamics regarding the decisions taken by the subjects to achieve development social goals;
- social-cost approach, which provides designing of institutional mechanisms for the system development, adapted to real situation in world markets, arising from economic objectives of modernization in the long and short term, and based on the assessment of existing experience of negative social-economic, socialecological and ecological-economic consequences of innovation-technological reformations in terms of money equivalent.

\section{Methods}

To implement effective policy, the authors developed risk assessment and management tools. They propose the formulation of a multi-criterion mathematical problem and the search for its optimal solution. Let there be a number of time intervals $t_{1}^{i}$, for each of which social risks are characteristic $r_{1}^{n}$. Every risk is described by a set of indicators $j_{1}^{m}$, quantitatively characterizing the interconnection harmony of the social and economic subsystems of the country. Thus, the state of the socialeconomic system at each moment of time can be recorded in the following form:

$$
\left\{x_{i r}^{j}, t=1 \ldots i, r=1 \ldots n, j=1 \ldots m\right\},
$$

where $x_{i r}^{j}$ is a set of indicators that characterize the state of the social and economic system during the period $t$.

To identify the risks affecting the social-economic system of the country, the authors' team conducted a survey in 30 subjects of the Russian Federation, 20 people were interviewed.

The general expert group covers 600 people and consists of two subgroups, surveyed in an equal proportion:

1) experts whose income level exceeds the average per capita per the subject of the Russian Federation;

2) experts whose income level does not exceed the average per capita per the subject of the Russian Federation.

The results of the survey made it possible to identify the following risks whose manifestation was noticed in all subjects of the Russian Federation studied (see Table 2).

Table 2. System of risks in the social and economic system of the country

\begin{tabular}{|c|l|}
\hline No. & Feature \\
\hline r.1. & Reduction in consumer demand \\
\hline r.2. & Increase in professional morbidity \\
\hline r.3. & Deterioration of conditions to found a family \\
\hline r.4. & $\begin{array}{l}\text { Deterioration of conditions to spend leisure } \\
\text { time }\end{array}$ \\
\hline r.5. & Increased environment pollution level \\
\hline
\end{tabular}

The level of the gravity of risk manifestations in the system is gauged based on the analysis of statistical data available to the general public. Threshold values of the authors' scale are defined based on the Cheddock correlation scale and are shown in table 3. 
Table 3. Classification of severity level of risks manifestation

\begin{tabular}{|l|c|c|c|c|}
\hline Correlation ratio & $0-0.30$ & $\begin{array}{c}0.31- \\
0.50\end{array}$ & $\begin{array}{c}0.51- \\
0.70\end{array}$ & $\begin{array}{c}0.71- \\
1.00\end{array}$ \\
\hline $\begin{array}{l}\text { Dependence } \\
\text { between social } \\
\text { and economic } \\
\text { processes }\end{array}$ & weak & $\begin{array}{c}\text { modera } \\
\text { te }\end{array}$ & $\begin{array}{c}\text { noticea } \\
\text { ble }\end{array}$ & high \\
\hline $\begin{array}{l}\text { Severity level of } \\
\text { risks } \\
\text { manifestation }\end{array}$ & minor & $\begin{array}{c}\text { modera } \\
\text { te }\end{array}$ & $\begin{array}{c}\text { signific } \\
\text { ant }\end{array}$ & $\begin{array}{c}\text { critic } \\
\text { al }\end{array}$ \\
\hline
\end{tabular}

In order to define strategic and tactical plans a quantitative interpretation of the results of social and economic system's functioning is called for that would comprise a set of the chief indicators characterizing its condition.

These indicators are identified by means of the econometric apparatus of a set of recursive equations (2) which consistently characterize the following:

1) the relation between the population size and standards of living in a Russian Federation subject;

2) the relation between the production volume of goods in the economic subsystem and the population size with standards of living in a Russian Federation subject;

3) the relation between the production volume of social services and the production volume of goods, population size and standards of living.

$$
\left\{\begin{array}{l}
\mathrm{P}=\mathrm{a}_{11}+\mathrm{a}_{12} * \mathrm{LQ}_{\mathrm{i}} \\
\mathrm{V}_{\text {ind }}=\mathrm{a}_{22} * \mathrm{P}+\mathrm{a}_{23} * \mathrm{LQ}_{\mathrm{i}}+\mathrm{a}_{24} * \mathrm{x}_{1} \\
\mathrm{~S}_{\mathrm{s}}=\mathrm{a}_{31} * \mathrm{~V}_{\text {ind }}+\mathrm{a}_{32} * \mathrm{P}+\mathrm{a}_{33} * \mathrm{LQ}_{\mathrm{i}}+\mathrm{a}_{34} * \mathrm{x}_{1}+ \\
+\mathrm{a}_{35} * \mathrm{x}_{2}
\end{array}\right.
$$

\begin{tabular}{|c|c|c|}
\hline Macroregulator name & Formula & Decryption \\
\hline $\begin{array}{l}\text { Value added tax } \\
\text { graduated rate }\end{array}$ & $\mathrm{VAT}=\mathrm{N}_{\mathrm{a} \text { bas }} * \frac{\mathrm{GRP}_{\mathrm{i}}}{\mathrm{GRP}_{\max }}$ & $\begin{array}{l}\mathrm{N}_{\mathrm{a} \text { bas }} \text { - basic value added tax rate according to the Tax Code; } \\
\mathrm{GRP}_{\mathrm{i}} \text { - gross regional product in the investigated region; } \\
\mathrm{GRP}_{\max }-\text { maximum GRP }\end{array}$ \\
\hline $\begin{array}{l}\text { Industrial enterprises' } \\
\text { state-regulated } \\
\text { allocations for } \\
\text { promoting staff health }\end{array}$ & $\mathrm{Z}_{\mathrm{D}}=\mathrm{P} * \mathrm{D} * \frac{\mathrm{RC}}{\mathrm{ND}} * \frac{\mathrm{TR}}{\mathrm{GRP}}$ & $\begin{array}{l}\mathrm{Z}_{\mathrm{D}}-\text { industrial enterprises' state-regulated allocations for } \\
\text { promoting staff health, } \mathrm{P}-\text { population; } \mathrm{D}-\text { percentage of } \\
\text { occupational diseases cases; RC - costs for of occupational } \\
\text { diseases treatment in the investigated region; ND - number of } \\
\text { cases of occupational diseases in the investigated region; TR - } \\
\text { industrial output; GRP - gross regional product }\end{array}$ \\
\hline $\begin{array}{l}\text { Financial investment } \\
\text { into school and pre- } \\
\text { school establishment } \\
\text { buildings }\end{array}$ & $\mathrm{GIS}=\sum_{\mathrm{i}=1}^{\mathrm{n}}\left(\frac{\mathrm{P}_{\mathrm{r}}}{\mathrm{AS}}-\mathrm{SN}_{\mathrm{i}}\right) * \mathrm{SIC}$ & $\begin{array}{l}\text { GIS - public investment into school and pre-school } \\
\text { establishment buildings; } n-\text { number of municipal districts; } \mathrm{P}_{\mathrm{r}} \\
\text { - number of pupils in a district; AS - average capacity of one } \\
\text { school; } \mathrm{SN}_{\mathrm{i}}-\text { number of schools in a district; SIC - } \\
\text { investments into construction of one establishment building }\end{array}$ \\
\hline $\begin{array}{l}\text { Financial investments } \\
\text { into culture and sport } \\
\text { establishment } \\
\text { buildings }\end{array}$ & $\begin{array}{c}\mathrm{GIC}= \\
=\left[\frac{P * A V * A C}{1000}-(R V+C N)\right] * \\
* C I C\end{array}$ & $\begin{array}{l}\text { GIC - investments into culture and sport establishment } \\
\text { buildings; AV - number of visits per } 1000 \text { citizens of the most } \\
\text { populated region; AC - average capacity of } 1 \text { building; RV - } \\
\text { number of visits per } 1000 \text { citizens of the investigated region; } \\
\text { CN - number of culture and sport establishment buildings; } \\
\text { CIC - investments into construction of one establishment } \\
\text { building }\end{array}$ \\
\hline $\begin{array}{l}\text { Rate for the emission } \\
\text { of } 1 \text { ton of pollutants } \\
\text { in the atmosphere }\end{array}$ & $\begin{array}{c}\mathrm{N}_{\mathrm{ER}}= \\
=\mathrm{N}_{\mathrm{E} R b} * \\
\frac{\Delta \mathrm{Q}_{\mathrm{P}}-\Delta \mathrm{Q}_{\mathrm{P}_{\_} \text {min }}}{\Delta \mathrm{Q}_{\mathrm{P}_{-} \text {max }}-\Delta \mathrm{Q}_{\mathrm{P} \_ \text {min }}}\end{array}$ & $\begin{array}{l}N_{E R}-\text { rate for the emission of } 1 \text { ton of pollutants in the } \\
\text { atmosphere; } N_{E R b}-\text { basic rate for the emission of } 1 \text { ton of } \\
\text { pollutants in the atmosphere; } \Delta Q_{P}-\text { the number of uncaptured } \\
\text { pollutants; } \Delta Q_{P_{2} m a x}-\text { pollutant emission in the most polluted } \\
\text { region; } \Delta Q_{P_{-} \text {min }} \text { - pollutant emission in the most unpolluted } \\
\text { region. }\end{array}$ \\
\hline
\end{tabular}

Table 4. System of macroregulators for country's social and economic system management [4] million people;

$\mathrm{LQ}_{\mathrm{i}}$ is the life quality of the population in the region under study;

$\mathrm{V}_{\text {ind }}$ is the volume of industrial production in the region under study;

$S_{\mathrm{s}}$ is the scope of services provided in the region under study;

$\mathrm{a}_{\mathrm{ij}}$ is the required parameters of the regression equation in the system;

$\mathrm{x}_{1}$ is state expenditure on the purchase of industrial goods in the region, million rubles.

The modelling is predefined by the principle of consistent mutual influence of the specified factors and systems. The developed model allows estimating the influence of the population's standards of living, which are affected by manifested risks, on the resulting indicators in the social and economic system. Consequently, a damage to the economy resulting from affected standards of living factors may be estimated with the help of this model. The damage is estimated as the difference between dependent variables in the recursive system before and after a standard of living factor is affected [5].

This approach allowed developing macroregulators (table 4), a set of risk management tools aimed at targeting factors of the population's standards of living and proportions of the national social and economic , system. This made it possible to implement a new type of national policy based on preventive strategic and tactical management principles. 


\section{Results}

The authors' proposed method was tested on the example of Perm Region. The econometric model obtained for this subject of the Russian Federation has the form:

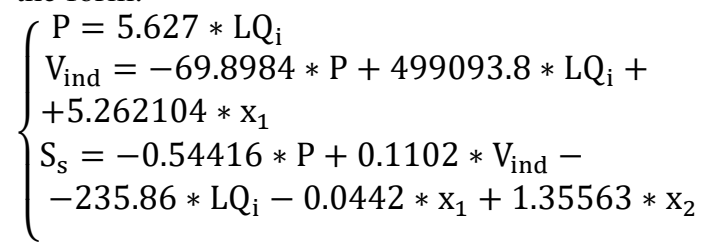

Analysis of the extent of risk manifestations in the region's social and economic system revealed that risks manifest themselves on a small scale in this subject of the Russian Federation. However, macroregulators presented in table 5 have been calculated in order to reduce them still more.

Table 5. Values for macroregulators aimed at levelling risks in the Perm Region in 2018, as defined by the authors

\begin{tabular}{|l|c|}
\hline Macroregulator name & Value \\
\hline Value added tax graduated rate, \% & 11.4 \\
\hline $\begin{array}{l}\text { Industrial enterprises' state-regulated } \\
\text { allocations for promoting staff health, in } \\
\text { thousands of roubles (by the example of Lukoil } \\
\text { Perm, LLC) }\end{array}$ & 195.1 \\
\hline $\begin{array}{l}\text { Financial investment into school and pre-school } \\
\text { establishment buildings macroregulator, in } \\
\text { millions of roubles }\end{array}$ & 589.75 \\
\hline $\begin{array}{l}\text { Financial investments into culture and sport } \\
\text { establishment buildings regulator, in millions of } \\
\text { roubles }\end{array}$ & - \\
\hline $\begin{array}{l}\text { Rate for the emission of 1 ton of pollutants in } \\
\text { the atmosphere (by the example of ammonium), } \\
\text { roubles per ton }\end{array}$ & 15.27 \\
\hline
\end{tabular}

After this the influence of the macroregulators on the population's standards of living was estimated, with key indicators characterizing the results of the social and economic system's functioning in the Perm Region reviewed. The values of potential opportunity costs for the Perm Region as a comparison between indicators before and after implementing the macroregulators can be seen in table 6 .

Table 6. Results of the model application in Perm Region

\begin{tabular}{|c|c|c|c|c|}
\hline \multirow[b]{2}{*}{ Indicator } & \multicolumn{2}{|c|}{ Variable value } & \multicolumn{2}{|c|}{ Deviation } \\
\hline & $\begin{array}{l}\text { Before } \\
\text { application }\end{array}$ & $\begin{array}{l}\text { Forecasted } \\
\text { value }\end{array}$ & absolute & relative \\
\hline $\begin{array}{l}\text { Life quality of } \\
\text { the population }\end{array}$ & 0.54 & 0.56 & 0.02 & +3.70 \\
\hline Population & 2611 & 3293 & 682 & +26.12 \\
\hline $\begin{array}{l}\text { Volume of } \\
\text { industrial } \\
\text { production }\end{array}$ & 1644154 & 1728161 & 84007 & +5.11 \\
\hline $\begin{array}{l}\text { Scope of } \\
\text { services } \\
\text { provided }\end{array}$ & 160204 & 173456 & 13252 & +8.27 \\
\hline $\begin{array}{l}\text { Severity level } \\
\text { of risks } \\
\text { manifestation }\end{array}$ & 0.014 & 0.013 & -0.01 & -7.14 \\
\hline
\end{tabular}

Following the analysis, the use of the tools not only reduces risks, but also reduces opportunity costs by transforming them into an additional source of developing the social and economic system of the Perm Region.

\section{References}

1. Guide to Integrated Risk Management. Treasury Board of Canada Secretariat, (2011).

2. V.N. Viatkin, V.A. Gamza F.V. Maevskiı̌ Riskmenedzhment: preventivnoe upravlenie. (AP «Nauka i obrazovanie», 2013).

3. A.S. Williams, M.L. Smith, P.C. Young Risk Management and Insurance (McGraw-Hill, New York, 1995).

4. U.V. Aftakhova, E.E. Zhulanov PNRPU sociology and economics bulletin, 4 (2019)

5. U.V. Aftakhova, E.E. Zhulanov PNRPU sociology and economics bulletin, 5 (2018) 